\title{
The politics of beer:
}

\section{Analysis of the congressional votes on the Beer Bill of 1933}

\author{
Eline Poelmans * \\ KU Leuven, Faculty of Economics and Business, campus Brussels \\ KU Leuven, LICOS Centre for Institutions and Economic Performance \\ Warmoesberg 26, B-1000 Brussels, Belgium \\ eline.poelmans@kuleuven.be \\ John A. Dove ${ }^{\circ}$ \\ Manuel H. Johnson Center for Political Economy \\ Troy University \\ Troy, AL 36079, USA \\ jadove@troy.edu \\ Jason E. Taylor ${ }^{\circ} \#$ \\ Central Michigan University \\ Mount Pleasant, MI 48858, USA \\ Taylo2je@cmich.edu \\ $\circ$ joint last author \\ \# corresponding author
}

* first author

\section{Published as :}

Poelmans, E., Dove, J.A. and Taylor, J.E. (2017). "The politics of beer: Analysis of the congressional votes on the Beer Bill of 1933”. Public Choice (ISSN: 0048-5829 / A-ISSN: 


\begin{abstract}
Nine days after he took office in March 1933, Franklin Roosevelt asked Congress to amend existing federal Prohibition policy so as to allow for the sale and consumption of $3.2 \%$ alcohol beer. Over the following eight days, the so-called "beer bill” was proposed, debated, passed and signed into law. This study analyzes the political decision making behind one of FDR's earliest New Deal policies. Specifically, we consider how voter preferences, representatives' ideologies, national party affiliations, and the influence of special interests affected legislative decision making. We find that special interests and party affiliations were particularly important drivers of congressional voting behavior.
\end{abstract}

Keywords: Beer legalization, Prohibition, special interests, median voter, representative ideology, New Deal, Franklin Roosevelt 


\section{Introduction}

Anderson and Tollison (1991) examine government outlays between 1933 and 1939—a period of significant growth in federal spending prowess in the United States (Wallis 1984)—and claim that the New Deal was not the federal government's idyllic Garden of Eden, but instead was “the more familiar stomping ground of Homo economicus." They show that the state-level distribution of New Deal spending was strongly influenced by congressional politics. Specifically, spending was associated with factors such as the tenure of a state's congressional delegation and whether the state had congressional membership on key committees or in key leadership positions. A host of other studies, such as Reading (1973), Wright (1974), Wallis (1998), Couch and Shughart (1998), Fleck (1999, 2001a, 2001b) and Kantor, Fishback and Wallis (2013), likewise have examined the role that politics_-presidential, congressional, or both—played in New Deal spending decisions. While disagreement exists as to the magnitude of politics' influences, the broad consensus is that the allocation of New Deal funds conformed in many ways to the predictions of public choice theory.

This paper dives deeper into the political economy of the New Deal by examining the determinants of the congressional vote to legalize beer containing $3.2 \%$ alcohol by weight (ABW) in March 1933. That decision was one of the earliest New Deal policies as Roosevelt asked Congress to formulate and pass legislation legalizing beer just nine days after he took office. The so-called "beer bill," which was supposed to bring in needed tax revenue and create jobs related to brewing, was passed eight days later. The analyses herein evaluate several factors that have been determined by public choice literature to be especially important in influencing legislators’ voting behavior. Specifically, we consider how general constituent preferences, the ideology of a particular representative (here Senator or House congressional delegation), and national party 
affiliation may have affected legislative decision making. We analyze those factors with respect to two separate votes in the Senate, the vote in the House, as well as the state-level decisions of how quickly to legalize beer after the federal reform.

Related to the latter point, passage of the beer bill did not mean that beer was legal nationwide. States generally had their own Prohibition policies in place, which had to be amended, and legalizing states needed to put together their own systems for control and taxation of beer. Fewer than half of states legalized on the first allowable day-April 7, 1933. Most of the remaining states had legalized beer by the end of 1933, although it remained illegal in five states at the beginning of 1934 . Thus, we explore the determinants of the speed with which states legalized beer after the bill’s passage.

The remainder of the paper is structured as follows: section 2 discusses the relevant public choice literature along with several theoretical considerations. Section 3 provides historical background surrounding beer legalization as well as anecdotal evidence supporting the theoretical discussion of section 2. Section 4 outlines our empirical model and reports the results. Section 5 analyzes the determinants of the speed with which states legalized beer after April 7, 1933. Section 6 concludes.

\section{Theoretical considerations regarding the vote on the Beer Bill}

An extensive literature has developed to explain congressional voting patterns. Typically, these studies have addressed the voting decisions by individual members of the US House, the Senate, or both chambers. One major strand of this research specifically has assessed the determinants of votes on US trade bills (Tosini and Tower 1987; Baldwin 1985; Baldwin and Magee 1985; Choi 
2015; Weller 2009; Marks 1993; Kahane 1996; Stegall and Jennings 1996). Each of these studies has addressed various factors that may be especially relevant to an individual legislator's support, including national party affiliation, constituent preferences, personal ideology, and special interest effects.

Levitt (1996) provides a more generalized theoretical model of the determinants of voting patterns by US Senators. He suggests that both individual ideology and the national "party line" play important roles in influencing a Senator's decision to vote for or against particular legislation. This latter observation has been corroborated by several studies suggesting that party allegiance plays a central role in an individual's overall success in Congress (Kiewiet and McCubbins 1991; Cox and McCubbins 1993; Weller 2009). Generally, breaking ranks with the party line, especially on issues considered to be important to a party position, results in retribution against that member in the form of less prestigious committee assignments or other sanctions. The beer bill had strong support from President Roosevelt and, hence, a vote against the bill may have been expected to bring significant repercussions for a member of the Democratic Party. Thus, we posit that a Democratic member of Congress would have been more likely to vote for the beer bill, ceteris paribus.

Another potentially important factor highlighted in the literature is the role of ideology. A central theme in the study of legislative voting behavior is the extent to which ideological preferences may influence how a particular legislator will vote on a given issue. Griffin (2008) argues that empirical assessments of roll-call voting must account for ideology to avoid an omitted variable bias. A major issue revolves around defining what exactly is meant by ideology (Burden, Caldiera and Groseclose 2000), and then determining how to measure such ideological preferences (Bender and Lott 1996; Lott 1987; Goff and Grier 1993). 
To the first point, legislative ideology can be broken down into personal and operative preferences, where personal ideology represents those views held internally by a legislator while operative preferences include not only internal views but any external influences as well (Rhode 1991). External influences can come from constituents, pressure from interest groups, or ideological preferences from other political actors (Jackson and Kingdon 1992). Given this, any quantitative decomposition and measurement of legislative ideology can become problematic_no measure can perfectly avoid operative preferences contaminating the measurement of personal preferences.

However, given the sizeable effect that personal ideology plays in legislative voting behavior, particularly within the Senate (Levitt 1996; McArthur and Marks 1988; Rhode 1994), we posit that a representative's own ideological position could also play an important role in voting behavior, ceteris paribus. Furthermore, given the longer terms Senators have relative to members of the House of Representatives (which better insulate Senators), and the presence of (generally) a more heterogeneous voter base for Senatorial elections than for House members, personal ideology could be expected to have a stronger effect in the Senate than in the House. Given that opposition to beer legalization tended to come from relatively more conservative individuals and groups, we posit that ideological conservativism will be negatively associated with beer legalization, ceteris paribus.

A number of scholars also have focused on the role that constituent preferences play in influencing legislative voting. Here, constituent interests, broadly construed, can come in a number of forms, but may generally be represented through broad voter interests (typically represented by the median voter) and other special interest groups that may be represented by particular industries or subsets of voters who may benefit directly or be harmed by a given piece 
of legislation. For example, drawing on the dual constituency hypothesis from Fiorina (1974), Levitt (1996) considers the influence that a legislator's support base has on his or her voting record, relative to the general electorate. His results indicate that while legislators are not generally responsive to broad voter preferences, they are much more responsive to their particular support bases.

Additional research related to trade legislation offers strong theoretical support for the notion that legislative behavior is influenced by voter preference and, in particular, that of the median voter. However, empirical results typically find either no—or at best a weak—impact on legislative decision making. Nevertheless, such findings may be explained by the ways in which voter and constituency preferences are measured (Choi 2015). On the other hand, most research in this vein indicates that particular special interest pressure plays an extremely important role in determining legislative voting behavior on trade legislation (Baldwin and Magee 1998; Coughlin 1985; Tosini and Tower 1987; Steagall and Jennings 1996) and more generally (Olson 1965; Tullock 1989). That result tends to hold regardless of the legislative chamber analyzed.

Given the implications of prior empirical work, we attempt to break down constituent effects in our empirical model and test whether voter preferences and/or special interest effects influenced voting patterns by examining not just Roosevelt's vote share in the 1932 election, but also the strength of the state's shift toward the Democratic Party between the presidential elections of 1928 and 1932. Alcohol legalization was a major platform position of the Democratic Party, ${ }^{1}$ suggesting that the Democratic Party’s rise to power would at least be partially explained by voter

\footnotetext{
${ }^{1}$ Specifically, a section of the Democratic Party's platform said, “we favor immediate modification of the Volstead Act; to legalize the manufacture and sale of beer and other beverages of such alcoholic content as is permissible under the Constitution and to provide therefrom a proper and needed revenue.” http://www.presidency.ucsb.edu/ws/?pid=29595
} 
preferences in favor of the legislation. Thus, we posit that to the extent that voter interests influenced legislative voting behavior, stronger support for the Democratic Party would increase the likelihood of voting for legalization.

With regard to the special interest effect, farmers of barley and hops—which were beer's two largest ingredients ${ }^{2}$-were expected to gain tremendously from legalization. In fact, in the month after the beer bill's passage, barley prices nearly doubled from 33 cents to 60 cents a bushel and the rise was attributed "largely to the legalization of beer."3 At the same time, hops prices tripled in the week between the passage of the beer bill and April 1, 1933, and shortages caused the prices to remain high throughout the summer of $1933 .{ }^{4}$ The other expected large economic winners from legalization were breweries who were operating in 1932 by selling nonalcoholic beer and brewers who had stopped making beer altogether during Prohibition, but were poised to reenter the industry after relegalization. If special interests affected voting behavior, we would observe members of Congress from states with significant beer-production-related interests to vote more in support of the legislation, ceteris paribus.

\section{The "Beer Bill" of 1933}

The $18^{\text {th }}$ Amendment to the US Constitution, which took effect in January 1920, prohibited the sale, manufacture, and transportation of "intoxicating liquors." The definition of intoxicating

\footnotetext{
${ }^{2}$ According to the 1935 Census of Manufactures, beer producers in the United States spent around \$70 million on barley and barley malt, \$11 million on hops, and around \$19 million on all other inputs, such as rice, grits, sugar, corn syrup and yeast (Census of Manufactures 1935, “Malt Liquors," Table 6, "Principal Materials Consumed, by Kind, Quantity, and Cost for the United States: 1935.”). Thus, barley represented around $70 \%$ of the total cost of raw material inputs into beer and hops around $11 \%$.

3 “Wheat Prices Sag as Trading Eases,” New York Times, April 26, 1933, p. 28.

4 “Slow in San Francisco.... Hop Prices Rise.” New York Times, April 2, 1933, p. N13.
} 
liquors was not, however, specified in the Constitution. The Volstead Act, which was passed as a companion to carry out the intent of the $18^{\text {th }}$ Amendment, specifically forbid beverages containing more than $0.5 \%$ alcohol by volume (ABV). Kyvig (1979) notes that this $0.5 \%$ figure, which had been pushed for by the Anti-Saloon League, was a surprise to many-including some advocates of Prohibition—who had assumed that beer and wine would still be allowed and that only liquor was to be outlawed. Federal Prohibition was repealed by adoption of the $21^{\text {st }}$ Amendment on December 5, 1933. However, on March 13, 1933, nine days after he took office, President Franklin Roosevelt sent a short memo to Congress asking for "modification of the Volstead Act in order to legalize the manufacture and sale of beer.” Beer legalization was a plank in the 1932 Democratic Party's campaign platform and proponents of the measure claimed that it would bring more revenue to federal coffers and provide an economic boost in sectors associated with brewing (such as agricultural, production, distribution and serving). Five hours after receiving Roosevelt's message, a subcommittee of the House Ways and Means Committee drafted a bill that would legalize $3.2 \%$ ABW beer at the federal level, but would allow states the option of keeping their own Prohibitions in place. ${ }^{5}$

\subsection{Congressional debate on the Beer Bill}

Representative Thomas Cullen of New York, the bill's sponsor in the House of Representatives, introduced the measure by saying that it "conforms in every respect with the platform approved by the Democratic National Committee.... I hardly think that any one will take issue with me when

\footnotetext{
${ }^{5}$ Three-point-two percent alcohol by weight (ABW) is around $4 \%$ alcohol by volume (ABV). That was the ABV of a typical American lager beer prior to Prohibition. For a modern comparison, Coors Light and Bud Light are 4.2 \% ABV today.
} 
I have the temerity to state that this measure was overwhelmingly endorsed by the American people” in November. ${ }^{6}$ In the debate that followed, Congressman Arthur Healey of Massachusetts noted that in New England "there are 16 breweries ready and 59 [others] getting ready to go into operation at an estimated expenditure of $\$ 70$ million and they will be prepared to employ in a short time some 15,000 workers."77 Freshman Representative Raymond Cannon of Wisconsin likewise testified that Milwaukee—which he called "the greatest beer city in all the world" —-would gain between 20,000 and 30,000 new jobs from legalized beer. In response to the platitudes regarding Milwaukee’s brewing prowess, Representative John Cochran of Missouri said, “Did the gentleman ever hear of St. Louis? ... I advise the gentleman in about 3 weeks to taste Budweiser.”8 Representative George Sadowski of Michigan was amused by the back in forth of his colleagues, but noted that "Detroit has just as good beer as theirs, and we are ready to go. [This bill] does not mean employment only for the men in my district, but all over the country—-the barrel factory, the grain men, everything together.”9

When Rep. Cochran was allotted his own time on the floor, he noted that passage of the bill would have the people of St. Louis singing "Happy Days Are Here Again” because "from the city of St. Louis to the four corners of the country, wherever it is permitted to be sold, beer will be shipped [and] thousands of men will go back to work.”10 Freshman Representative James Claiborne, also of Missouri, likewise testified that "in my district there are many brewing interests, among them Anheuser-Busch ... nowhere are people better prepared to furnish America with good

\footnotetext{
${ }^{6}$ Congressional Record, $77^{\text {th }}$ Congress, Record 310, March 14, 1933 p. 375.

${ }^{7}$ Congressional Record, $77^{\text {th }}$ Congress, Record 310, March 14, 1933 p. 378.

${ }^{8}$ Congressional Record, $77^{\text {th }}$ Congress, Record 310, March 14, 1933 p. 389.

${ }^{9}$ Congressional Record, $77^{\text {th }}$ Congress, Record 310, March 14, 1933 p. 393.

${ }^{10}$ Congressional Record, $77^{\text {th }}$ Congress, Record 310, March 14, 1933 p. 394.
} 
beer, give work to many, and pay larger taxes than we are in St. Louis." ${ }^{\prime 11}$ In fact, cities such as St. Louis, Milwaukee and Chicago, which were hubs of brewing prior to Prohibition, still had many breweries in operation producing nonalcoholic beer. ${ }^{12}$ If beer became legal again, areas with existing breweries would be in prime positions to take quick advantage of the sharp rise in demand.

Many representatives appealed to the gains the bill would bring to agricultural interests. John Boylan of New York expressed support for the bill because "It will help the farmer by restoring his barley crop and increase his sales by a hundred million bushels a year." ${ }^{\text {13 }}$ Another New York representative, James Meade, noted that an important rationale behind the push for Prohibition during the First World War was to save crops to feed our soldiers. However, "today the elevators of the Nation are jammed to capacity, with surplus crops.... If prohibition was necessary then to conserve our crops, modification and repeal are necessary today to reduce our huge surplus." ${ }^{14}$

The main sentiment expressed by those who spoke in opposition to the bill was that it would bring back the saloon culture that the United States had fought so hard to eradicate in the decades leading up to Prohibition. Texas Representative Thomas Blaton opened the opposition's time on the floor by saying that the bill would "inflict beer saloons again upon the country [and] we who oppose saloons must have the opportunity of placing in the Record our everlasting condemnation of them.”15 Fellow Texan William McFarlane noted that, “A drunken citizenship cannot drink its way to prosperity.” ${ }^{16}$ Representative Malcolm Tarver of Georgia stated that those

\footnotetext{
11 Congressional Record, 77 ${ }^{\text {th }}$ Congress, Record 310, March 14, 1933 p. 397.

12 “Brewers at Chicago Lay in Barley Malt.” Wall Street Journal, March 31, 1933, p. 1.

13 Congressional Record, $77^{\text {th }}$ Congress, Record 310, March 14, 1933 p. 399.

14 Congressional Record, $77^{\text {th }}$ Congress, Record 310, March 14, 1933 p. 389.

${ }^{15}$ Congressional Record, $77^{\text {th }}$ Congress, Record 310, March 14, 1933 p. 373.

${ }^{16}$ Congressional Record, $77^{\text {th }}$ Congress, Record 310, March 14, 1933 p. 393.
} 
who vote yes "wish to make profits from the debauchery of their fellow men or save themselves from taxes at the expense of the poor."17

After around four hours of debate, the beer bill passed the House of Representatives by a vote of 316 to 97 . Kansas was the only state to have a unified delegation vote against the bill, while majorities of the House delegations representing four states, Mississippi, Arkansas, Georgia and Texas, voted against the bill. On the other side, all 13 of Missouri's representatives voted in favor of the bill. In Wisconsin, 9 out of 10 representatives voted in favor. In Illinois, 23 of the 26 representatives voted in favor of the bill. This voting pattern provides anecdotal evidence in favor of the special interest hypothesis - the states that voted against the beer bill had little or no connection to beer brewing, nor to the growing of inputs into beer production, such as barley or hops. On the other hand, states like Missouri and Wisconsin, which had large brewing interests, would be important beneficiaries of the beer bill's passage.

After its passage in the House, the bill went to the Senate under the sponsorship of Senator Pat Harrison of Mississippi. California Senator William McAdoo succeeded in amending the bill to include the legalization of wine of up to $3.2 \%$ alcohol—essentially taking up parts of a light wine bill previously proposed in the House by Representative Clarence Lea of California's $1^{\text {st }}$ Congressional District (which included wine producing counties such as Sonoma and Mendocino, amongst others). ${ }^{18}$ While many senators expressed skepticism that wine of $3.2 \%$ would be palatable, Sen. McAdoo noted that a "delectable" soft-drink of 3.2 percent could be made with

${ }^{17}$ Congressional Record, $77^{\text {th }}$ Congress, Record 310, March 14, 1933 p. 388.

18 “Wine of 3.2\% Added to House Beer Bill in Senate Report.” New York Times, March 16, 1933, p. 1. 
wine as the base. ${ }^{19}$ The push from California representatives to include $3.2 \%$ wine in the beer bill provides further anecdotal evidence in favor of the special interest hypothesis since California was by far the largest wine growing state in the nation.

Senator Albin Barkley of Kentucky succeeded in amending the bill to allow beverages up to only $3.05 \%$ ABW, which was the level that British law had declared "non-intoxicating."20 The issue of beer's "intoxicating" effects was important because the $18^{\text {th }}$ Amendment to the Constitution prohibited "intoxicating liquors"-although again it left it to Congress to determine just what the definition of "intoxicating" would be. Thus, much of the Senate debate focused upon whether or not $3.2 \%$ (or $3.05 \%$ ) beer was in fact "intoxicating" - if it was, the bill could be viewed as unconstitutional. Senator Kean of New Jersey said "I believe that beer having the alcoholic content permitted under this bill is a nonintoxicant.” He noted that Germans produced beer of this alcohol level and "The men drink it, their wives drink it, and their children drink it, and none of them are intoxicated. I have known a man in the city of Newark who drank 29 glasses a day of this beer and he was never intoxicated, and he lived to be nearly 90 years old." ${ }^{21}$ While some senators opposed the bill on constitutional grounds, others like Senator William Borah of Idaho opposed the bill because the saloon "was the most hideous institution with which organized society ever had to deal.,22

\footnotetext{
19 “3.2 Per Cent Beer Passed by Senate.” New York Times, March 21, 1933, p. 1. Incidentally, wine coolers, which became popular in the 1980s, are indeed around $3.2 \%$ ABW, i.e. around 4 $\% \mathrm{ABV}$.

${ }^{20}$ Congressional Record, $77^{\text {th }}$ Congress, Record 503, March 16, 1933 p. 526.

${ }^{21}$ Congressional Record, $77^{\text {th }}$ Congress, Record 503, March 16, 1933 p. 535-6.

${ }^{22}$ Congressional Record, $77^{\text {th }}$ Congress, Record 503, March 16, 1933 p. 512.
} 


\subsection{Passage of the Cullen-Harrison Act}

The Cullen-Harrison bill passed the Senate on March 16, 1933, by a 43-30 vote. The final step was to resolve the differences between the House and Senate versions in the reconciliation process. New York Representative James Wadsworth, who despite being a Republican—-the drier of the two parties—-had long advocated a wet position, pledged that the House would stick to its guns on the $3.2 \%$ level, which it did. ${ }^{23}$ The most vocal opponent of the bill during the reconciliation hearings was Representative Thomas Blanton of Texas, who warned the country would see spikes in deaths caused by automobile fatalities as well as disease in general. The primary employment the bill would create, Blanton argued, were jobs for police and undertakers. ${ }^{24}$

Much of the reconciliation debate focused on beer's ABW content, which the media dubbed "The Great Percentage War." The opposition maintained that either percentage was, in fact, intoxicating, and hence a violation of the $18^{\text {th }}$ Amendment. A Chicago lawyer argued that "should some purchaser refuse to pay for it on the ground that it is illegal because in violation of the Constitution," a decision from the Supreme Court may be necessary. ${ }^{25}$ Still, most commentators dismissed this issue-the New York Times editorialized that the controversy was "absurd", noting that it was up to "Congress to define intoxicating beverages under the $18^{\text {th }}$ Amendment. If Congress has defined, it can redefine.,26

On March 20, the Senate approved a reconciled bill for $3.2 \%$ beer and wine by a vote of 43 to 36 - the vote was a bit tighter than the one on March 16, as some Senators apparently could not bring themselves to vote for the $3.2 \%$ level versus the $3.05 \%$ level in the prior bill. The House

\footnotetext{
23 “Upholds 3.2 Per Cent Beer.” New York Times, March 17, 1933, p. 3.

24 “Beer Bill Signing Delayed by Mix-Up.” New York Times, March 22, 1933, p. 1.

25 "Mid-West Cheered by Banks and Beer." New York Times, March 19, 1933, p. E6.

26 “Beer for Revenue.” New York Times, March 14, 1933, p. 14.
} 
likewise passed the reconciled bill without a formal roll call on March 21. President Roosevelt signed the bill on March 22. ${ }^{27}$ The Cullen-Harrison Act prohibited the sale of 3.2 beer to anyone under 18 and created a federal tax of $\$ 5$ per barrel, i.e., around a penny per serving of beer (which typically cost around 10 cents at that time). Brewers also had to pay a $\$ 1,000$ per year federal license fee; states and localities could—and often did—also impose their own fees or taxes. It was estimated that beer legalization would bring between $\$ 125$ and $\$ 375$ million to the federal government each year. ${ }^{28}$

In those states that did not have their own laws against beverages below $3.2 \%$ alcohol in place, beer would become legal on April 7, 1933 (states could begin to produce beer immediately and hold it until the legalization date). ${ }^{29}$ Most states, however, did have prohibitions on their books, so that state legislatures wanting legal beer on April 7 had to act quickly. For example, the state legislature of New York began to formulate its plan for beer as early as March 14, the date the bill passed the House of Representatives. On March 16, the Colorado State Senate passed a bill legalizing $3.2 \%$ beer by a vote of 26 to $5 .{ }^{30}$ On March 22, the Vermont General Assembly voted 149 to 93 to legalize 3.2 beer while giving cities a local option to keep it prohibited. ${ }^{31}$ On April 7,

${ }^{27}$ It should be noted that "sacramental wines" were allowable under national Prohibition. Incidentally, a wine bill, which would have allowed the production of wine up to $11 \%$ alcohol, was later proposed by Representative Lea of California. On June 8, the House Ways and Means Committee heard testimony regarding the bill. Representative Cullen of New York was intent on making sure that sugar could be added to the $11 \%$ wines since this was important for the many wines made in the Finger Lakes region of New York ("Dry Chief Backs Light Wine Bill," New York Times, June 9, 1933 p. 15). On June 12, the Ways and Means Committee voted 11 to 9 to postpone consideration of the bill until the next congressional session. The bill was never taken up because Prohibition was repealed in December 1933.

28 "House Passes 3.2 Beer Bill.” The Washington Post, March 15, 1933, p. 1.

${ }^{29}$ April 7 is currently known as "National Beer Day" in the United States in homage to beer's legalization on that date in 1933.

30 "Colorado Senate Passes Beer Bill.” New York Times, March 17, 1933, p. 5.

31 "Indiana adds many rules to legalized beer." Chicago Tribune, March 23, 1933, p. 2. 
1933, beer became legal in 21 of the 48 states. Over the next eight months-prior to the end of federal Prohibition in December-22 more states legalized $3.2 \%$ beer. Five other states chose to remain dry even after national Prohibition ended. Kansas became the last state to legalize beer in May 1937. Of course, many states—by 1940, 30 out of 48 — had local options whereby cities or counties could choose to remain dry. ${ }^{32}$ Table 1 lists the date of beer legalization in each state, the percentages of states' congressional delegations voting in favor of the beer bill, as well as some state-level data that will be used in our empirical analysis.

\section{[Insert Table 1 About Here]}

\section{Political economy of beer legalization in the US House and Senate}

In this section, we explore the state-level factors that influenced voting behavior on the beer bill. As noted, the literature highlights four main factors that may impact a legislator's decision to vote for or against a particular bill: 1) personal ideological preferences, 2) voter preferences, 3) industrial special interest effects, and 4) national party identity.

The final two columns of Table 1 report the quantities of barley and hops produced by each state in 1929. States in the upper Midwest, such as the Dakotas and Minnesota, led the way in barley production, both in absolute and per capita terms. Still, every state except Florida produced at least some barley. Hops, on the other hand, were produced in just four states-Oregon was the largest with 18.4 million pounds, California was second with 9.7 million pounds, Washington ranked third with 5 million pounds, and New York State, which led the nation in hops production

${ }^{32}$ United States Brewers Association Brewer's Almanac, October 2, 1940, p. 78. 
in 1899, with around 17 million pounds, produced only around 322,000 pounds of hops in 1929 because the industry had almost died there in the decade after Prohibition. ${ }^{33}$

Columns 4, 5 and 6 of Table 1 report data on the number of breweries per million people in each state for both 1914 and 1932, as well as the per capita barrels of beer produced by each state in 1914 (beer production data by state are not available for 1932). ${ }^{34}$ Data on the number of breweries were assembled from the American Breweriana Association, which reports the years of operation and the locations of every brewery in the United States from the $17^{\text {th }}$ century to today. We choose to examine the number of breweries and the output of breweries in 1914 as a proxy for pre-Prohibition brewing activity rather than 1919 (the year before federal Prohibition was implemented) because many states had imposed their own prohibitions during World War I. In 1914, the average state had 14.3 breweries per million people. Pennsylvania ranked first in aggregate number of breweries with 237, but ranked $6^{\text {th }}$ in the population-adjusted measure with 31 breweries per million people. States in the Midwest as well as on the West Coast tended to have more breweries relative to population in 1914 than the rest of the country. Wisconsin led the way with 66.84 breweries per million people.

To analyze the determinants of congressional votes on the beer bill we consider the following regression:

$$
\begin{aligned}
\text { YESBEER }_{i}= & \beta_{0}+\beta_{1} \text { Ideology }_{i}+\beta_{2} \text { Democrat }_{i}+\beta_{3} \text { pctFDRvote }_{i} \\
& +\beta_{4} \text { Voteshift }_{i}+\beta_{5} \text { Brewinginterests }_{i}+\beta_{6} \text { Agriculture }_{i}+Z_{i}^{\prime} \delta+\varepsilon_{i}
\end{aligned}
$$

where

${ }_{33}$ Barley output data for each state are from the 1930 Census of Agriculture. Hops data are from Table 2 of “An Economic Study of the Hop Industry in Oregon,” Agricultural Experiment Station, Oregon State Agricultural College, Station Bulletin 288, June 1931.

${ }^{34}$ Barrels of beer produced in each state are from Cherrington (1915). 
$\operatorname{YESBEER}_{i}=$ Senator $i$ 's vote $($ yes $=1$, no $=0)$ on the Cullen-Harrison Act on March $16^{\text {th }}$ (or March $20^{\text {th }}$ ). For the analysis of the House vote, this is the percentage of the House delegation in state $i$ voting yes on the bill in the March 14 vote.

Ideolog $y_{i}=$ Senator $i$ 's DW-NOMINATE score, discussed in detail below, for the $73^{\text {rd }}$ Congress. For the analysis of the House vote, the average DW-NOMINATE score of the state's House delegation is substituted.

Democrat $_{i}=$ A dummy variable for Senator i's party affiliation with a “1” representing Democrat and " 0 " otherwise. For the House analysis, this variable represents the percentage of state $i$ 's House delegation that is affiliated with the Democratic Party.

pctFDRvote $_{i}=$ The percentage of the popular vote that FDR received in state $i$ in the 1932 election.

Voteshift $_{i}=$ The percentage change in the Democratic vote share for president in state $i$ between the 1928 and 1932 presidential elections.

Brewinginterest $_{i}=$ For this variable we separately employ three different proxies: the number of breweries operating in state $i$ in 1914, divided by state $i$ 's population in 1910; the number of breweries operating in state $i$ in 1932, divided by state $i$ 's population in 1930; and the number of barrels of beer produced in state $i$ in 1914, divided by state $i$ 's population in $1910 .{ }^{35}$

Agriculture $_{i}=$ Pounds of hops and barley produced by state $i$ in 1929, divided by that state's population in 1930.

${ }^{35}$ State population data were from the 1910 and 1930 Census of Population. 
Because the dependent variable in the Senate regressions—a "yes" or "no" vote on beer— is binary ( 0 or 1 ), we use a probit estimation method. ${ }^{36}$ In terms of predictions, as discussed in section 2, we expect the coefficients on brewing interests and agriculture to be positive for political economy reasons-i.e., politicians vote in the interests of key organized constituents. We expect Democrat to be positive since Democratic congressional representatives generally were more sympathetic to the "wet" position than Republicans (although the issue was far from consistent along party lines). Furthermore, we also expect that, given the importance that FDR placed on the passage of this legislation, not toeing the "party line" and voting in accordance with party identity could be viewed as having potentially serious negative ramifications for a Senator. Therefore, Democratic Party affiliation should have a strong positive impact on the likelihood of supporting the bill.

In order to measure an individual representative's ideology, we include the DWNOMINATE score for each Senator. First developed by Poole and Rosenthal (1984), this score measures the ideological position on a left-right spectrum of each member of Congress from the $1^{\text {st }}$ to the $113^{\text {th }}$ Congress. The measure is based on the roll-call voting record of each representative and applies techniques akin to factor analysis to locate each individual member of congress within a two-dimensional vote space. This vote-predicting space is scaled between “- 1 ” and " +1 ”, with

\footnotetext{
${ }^{36}$ Importantly, a number of senators abstained from voting on both the March $16^{\text {th }}$ bill and on the amended bill on March $20^{\text {th }}$. Therefore, those abstentions are excluded from the analysis. Specifically, there were 22 abstentions for the March $16^{\text {th }}$ vote and 15 abstentions for the March $20^{\text {th }}$ vote. Interestingly, there do not appear to be any clear patterns that emerge. Minnesota was the only state who's entire delegation abstained from both votes, while the entire state delegations of Kentucky, South Carolina, and Wyoming abstained for the March $20^{\text {th }}$ vote. An evaluation of the abstention patterns based on the median value of each of the main variables of interest indicates that only four of the abstentions occurring on the March $20^{\text {th }}$ vote were from states with above the median number of brewing interests in 1932. Otherwise, there appears to be a fairly even split.
} 
“ -1 ” representing a more liberal ideology and a “+1" a more conservative one. ${ }^{37}$ If personal ideology played a role in the decision to vote for or against beer legalization, then we would expect personal conservatism to be negatively associated with the likelihood of voting yes-i.e., a negative coefficient in the regression results.

As noted earlier, a number of issues arise with any attempt to measure and evaluate legislative ideology, and DW-NOMINATE is no exception. First, any labels of liberal or conservative that these scores may provide are ex-post interpretations based on a given set of rollcall votes. Additionally, given that these scores are based on roll-call votes, which are themselves influenced by any number of external factors - including constituent preferences and other nonpersonal ideological factors - the score may not be perfectly measuring personal ideological preferences. To this latter point, Fleck (2002) finds evidence to suggest that the ideological divergence and drift that were observed with the DW-NOMINATE scores throughout the New Deal—culminating in coalitional realignments after passage of the Fair Labor Standards Act (FLSA) in 1938-were driven largely by constituent interests.

While no measure can capture legislative ideology perfectly, Burden, Caldeira and Groseclose (2000) find that most measures using roll call voting records, including DWNOMINATE scores, are able to operationalize ideology at least as well as any alternatives do. Additionally, while those authors admit that any measure of ideology based on roll-call votes will be biased by external factors, they still find that such measures serve as reasonable proxies for personal ideology and are the best measures we have of legislative ideology in general. Finally,

\footnotetext{
37 These data are available at legacy.voteview.com/dwnomin.htm. A much more thorough discussion of these scores and the construction of the index is laid out in Poole and Rosenthal (2007).
} 
while it may be the case that the DW-NOMINATE scores were drifting owing to changing constituent interests throughout the New Deal, we do not believe this to be a serious a concern for our study of the beer bill. As mentioned, the drift happened over time across several legislative sessions, culminating with the coalitional realignment that occurred after the passage of the FLSA five years later. However, our study is concerned with only one piece of legislation and, importantly, it was one of the very first pieces of New Deal legislation. Given all of these considerations, we believe that DW-NOMINATE provides a suitable, although not perfect, proxy for personal legislator ideology.

For this exercise, we include both the first and second dimension DW-NOMINATE scores. As Poole and Rosenthal (2007) note, the first-dimension scores tend to have better predictive power and are usually associated with divergences based on economic issues, while the second dimension tends to explain regional differences driven by race, civil rights, slavery and other social issues.

Additionally, we include the state-level vote share that Roosevelt received in 1932 as a proxy for voter preferences and the location of the median voter. We also include the state-level percentage change in the Democratic presidential vote share between the elections of 1932 and 1928 to account for how strong the electoral tide was moving in each state toward the sitting president. Roosevelt had pledged sweeping new legislation to combat the steep economic depression-included amongst these policies was the legalization of beer. If the beer legislation was viewed as an issue that helped bring about Roosevelt's landslide electoral victory in the fall of 1932, this could have resonated with a state's congressional delegation, consistent with the median voter theory. On the other hand, as noted earlier, some studies show that voter preference 
is not a strong predictor of a legislator's decision to vote for or against a given piece of legislation, especially in the face of special interest effects.

Finally, we also include a number of control variables that might influence the decision to support the beer bill. First, we include tenure of a given senator. The election of 1932 swept a number of new members of Congress into office, and those members may have been more likely than longstanding members to vote for beer legalization (particularly if it was part of the platform they had campaigned on). We also control for the percenaget of the population of a state that was Catholic — Okrent (2010) notes that Catholics, many of whom had come from Ireland, Italy and Eastern Europe, generally were against Prohibition. In fact, Rhode Island and Connecticut—-two of the most Catholic states in the country-were the only two states that did not ratify the $18^{\text {th }}$ Amendment. As percent Catholic by state is not available in 1933, we employ the average of the percentage of the population that was Catholic in each state in the two nearest years, 1926 and $1936 .{ }^{38}$

Another factor that could have influenced the state-level vote was economic need since the beer bill was pushed largely pushed as an economic recovery bill. Representatives from those states hit hardest by the Depression-i.e., those that experienced the largest declines in employment or manufacturing output—may have been more likely to vote in favor of legalization if they viewed it as a potential tonic for their economic woes. In fact, Poelmans, Raisanen and Taylor (2017) show that states that legalized beer, and particularly those that had large brewing traditions, saw significantly larger employment gains than those that did not legalize. Again, those effects were widely anticipated as legalization proponents suggested that the brewers dray would

\footnotetext{
${ }^{38}$ These data are from the Association of Religion Data Archives, http://thearda.com/Archive/ChState.asp
} 
bring back prosperity as well as beer. Thus, we include state-level data on the value of manufactures in 1929 and the change in employment in manufacturing between 1929 and $1931 .{ }^{39}$ We expect the coefficient on the change in manufacturing employment between 1929 and 1931 to be negative under the reasoning that the states that were hit hardest by the Depression (i.e., saw the largest declines in those variables) might have felt that beer legalization would have helped turn their economic fortunes around. We have no strong priors regarding the estimated sign on the value of manufacturing per capita in 1929. Lastly, Fleck (2002) and Seltzer (1995) suggest that Southern politics played a role in the passage of New Deal legislation. Therefore, we include a dummy variable for Southern states based on the US Census Bureau’s Census Regions.

\subsection{Analysis of Senate votes on March 16 and March 20, 1933}

Table 2 reports the results. Specifications 1 through 3 report estimates for the Senate vote on March $16^{\text {th }}$, while specifications 4 through 6 report those for the vote on March $20^{\text {th }}$. The specifications vary with respect to the "brewing interests" variable employed. Specifications 1 and 4 include the per capita number of breweries in each state in 1932, specifications 2 and 5 include the same measure, but for 1914, while specifications 3 and 6 include the per capita number of barrels produced in each state in 1914.

[Insert Table 2 About Here]

${ }^{39}$ We employ the change in manufacturing between 1929 and 1931 rather than 1929 and 1933 (which is also a Census year) since the 1933 data would have been influenced by beer legalization. Data on number of wage earners (average for the year) and values of products were collected from the Statistical Abstract of the United States, 1935, Table 761, "Summary for all Manufacturing Industries Combined: By Geographic Divisions and States." 
The coefficients on both dimensions of Senator ideology (DW-NOMINATE) suggest that relative conservatism was correlated with a lower likelihood of voting for beer legalization (with the exception of specifications 4 and 6 on the first dimension and specification 3 on the second dimension); however, the coefficients are never statistically significant. As expected, being a Democrat made a Senator more likely to vote yes to beer, ceteris paribus, consistent with the partyline hypothesis. Voter preference, however, does not appear to have had a significant impact on a Senator's decision to vote for beer legalization, once controlling for the legislator's political and ideological leaning. Admittedly, political ideology factor nevertheless may be playing an important role in the outcome observed. In fact, the coefficients on the percentage of the vote for FDR in 1932, though typically positive, was never significant, while the coefficients on the shift toward FDR in 1932 from Democratic Nominee Al Smith in 1928, were generally negative, and were in most cases statistically significant. This finding suggests that more support for FDR actually reduced the likelihood of voting yes, ceteris paribus.

The coefficients on Senator tenure were positive and generally significant for the March 16 vote, suggesting that those members of the upper chamber with longer tenures were more likely to vote yes than otherwise-which is the opposite of what we expected (though the coefficients are insignificant for the March 20 vote). Given the specifics of the vote at issue, one interpretation is that this result may reflect longer tenure being associated with more consistent representation of constituent interests by a legislator. In terms of the economic variables, the coefficients do not support a story of a state's economic need-i.e., how hard it was hit by the Depressioninfluencing congressional voting behavior. The percentage of Catholic inhabitants in a state had no significant effect on Senator voting behavior, ceteris paribus. Finally, Senator's from Southern 
states were less likely to support legalization, ceteris paribus, although this result is not statistically significant.

The coefficients on the special interest variables, on the other hand, suggest that brewing interests played important roles in influencing voting behavior. Specifically, brewery interests, whether measured by breweries per capita in 1932, 1914, or barrels produced per capita in 1914, had a positive and statistically significant effect in every specification. The coefficients on agricultural interests—i.e., the amount of barley and hops produced per capita in 1929—were generally positive, though not statistically significant. The results of Table 2 suggest that special interests and party membership were important determinants of the Senatorial vote on beer while the evidence for legislator ideology is weak at best and no evidence is found whatsoever that constituent/median voter preferences played any role in voting behavior, again once the political and ideological disposition of a Senator is controlled for. Interestingly, it would appear that the votes within the Senate are somewhat harder to explain relative to the House. Though beyond the scope of this current study, a better understanding of the factors that might drive this divergence would be worthy of future research.

\subsection{Analysis of House vote of March 14, 1933}

Next, we analyze the vote on the beer bill in the House of Representatives. For our controls, we continue to use data aggregated at the state level because, unfortunately, no congressional district level data are available for analysis from that period. However, we still believe that important insights can be gained with respect to the factors that motivated support for the beer bill within the 
House of Representatives. ${ }^{40}$ Given that we only have state-level data available to us for key independent variables, we now employ as the dependent variable the percentage of each state's entire delegation to the House of Representatives voting "yes." As the dependent variable is bounded between zero and one, we estimate OLS, Tobit, and fractional logit estimates for each specification. We also include all of the variables discussed previously; however, some changes with respect to the ideological and party affiliation variables are necessary. In order to proxy for them, we employ the average DW-NOMINATE score for each state's house delegation and the percentage of each state's delegation affiliated with the Democratic Party respectively. Again, we employ the same three separate measures for brewing interests. Table 3 presents the results.

\section{[Insert Table 3 About Here]}

The coefficients on representative's ideology (DW-NOMINATE) are always negative and statistically significant in the second dimension (though not the first)—i.e,. as we expected, the more conservative the delegation was, the less likely it was to vote "yes" on the beer bill. Once again, party loyalty played an important role in the vote as the coefficient on the delegation's

\footnotetext{
${ }^{40}$ While a somewhat more informative analysis could include county-level data, which is more readily available for some of the variables, including religious affiliation, data on the beer industry and agricultural production are available only at the state level. Furthermore, given the prevalence of heavily gerrymandered House districts from the $73^{\text {rd }}$ Congress (see Martis 1982, p. 167 for a detailed breakdown), even the use of county-level data would still require a significant amount of subjectivity on the researcher's part to decide how best to match counties to particular districts. For these reasons, we continue to employ state-level data in the analysis. However, we did consider one specification that evaluated each individual Representative's vote as a dependent variable using a probit model with those variables that were available at the district level (party affiliation, DW-NOMINATE scores and a dummy variable for Southern states) as explanatory variables. The results conform to what we find using state-level data—members of the Democratic Party were more likely to vote "yes", while personal conservatism and individuals from the South were more likely to vote "no". All variables, except the first dimension DW-NOMINATE scores were statistically significant at conventional levels. These results are not reported in the interest of space, but are available upon request.
} 
percentage Democrat is positive and is statistically significant in six of nine specifications. On the other hand, House representatives' votes were not strongly influenced in favor of legalizing beer by the results of the landslide presidential vote for FDR, as the coefficients on FDR's vote share in 1932, and on the shift in that vote from 1928 to 1932, were not statistically significant, and were in fact generally negative (as was also true in the Senate vote). Hence, no evidence is found in support of the constituent preferences/median voter hypothesis with respect to votes on the beer bill in the House.

With respect to socioeconomic control variables, the results of the vote in the House are a bit different than those in the Senate. Specifically, the coefficients on percentage Catholic are generally negative though not statistically significant—-the more Catholic a state was, the less likely its House delegation was to vote for beer. Also, the coefficient on the value of manufacturing in 1929 is negative and significant, suggesting that manufacturing states were more likely to vote against beer.

Perhaps what is most important, the results again suggest a major role for brewing interests, at least when those are measured by number of breweries per capita in either 1932 or in 1914 . Thus, consistent with the results of the Senate regressions, we find that the major determinants of the vote in the House were special interests related to brewing, party affiliation (Democrats more likely to vote yes and Republicans to vote no), and representative ideology, as measured by the second dimension DW-NOMINATE scores. 


\subsection{Qualitative analysis: The congressional debate}

Congressional representatives either vote yes or no on a bill—a binary response. A way to get a bit more at the qualitative strength of politicians' advocacy of - or opposition to-a bill is to analyze which politicians took the time to prepare and deliver formal testimony during the congressional debate. We earlier provided anecdotal evidence by quoting some members of Congress who testified for or against the beer bill. Here we take a more comprehensive approach. During the four hours of debate in the House of Representatives on March 14, 1933, of the 413 members who ultimately voted on the bill, 37 were given control of the floor to speak on the efficacy of the beer bill. Twenty-seven spoke in favor of the bill, while 10 spoke in opposition to it. On March 16, 1933, the Senate debated the bill. Of the 73 Senators who ultimately would vote (21 did not vote because they were not in attendance), 18 were given the floor and 10 of these spoke in opposition, while eight spoke in favor. Table 4 lists each congressional speaker's name and state as well as whether the testimony was in favor or against the bill. The speakers are ordered in the table by the presence of brewing interests in their state-specifically by how their state ranked in barrels of beer produced in 1914. This ordering allows us to examine more closely the special interest hypothesis as it relates to the politics of beer.

[Insert Table 4 About Here]

With respect to members of the House, a very clear pattern emerges. Members from states with greater brewing traditions prior to Prohibition—such as those from New York, Pennsylvania, Wisconsin, Ohio, Illinois and Missouri, were generally those who spoke in favor of the bill, while those who were opposed to it were generally from states like Texas, Maine, Oklahoma and Kansas, which had little or no brewing traditions. In the Senate, the pattern is a bit less striking, although it still holds broadly. In contrast to the debate in the House, relatively few senators from large beer 
producing states such as Wisconsin, Illinois, Pennsylvania or New York testified. Senator Roscoe Patterson of Missouri spoke against the bill, in contrast to his delegation colleagues in the House who all voted in favor, because he felt that it was a farce to say that $3.05 \%$ or $3.2 \%$ beer was nonintoxicating, making the beer bill in violation of the $18^{\text {th }}$ Amendment to the Constitution-a Constitution that he said he had taken an oath to uphold. ${ }^{41}$ Senator Simeon Fess of Ohio also testified against the beer bill, despite his state having a fairly strong brewing tradition, saying that no good "could come out of the saloon as an institution." ${ }^{2}$ It is interesting to note that both Fess and Patterson lost their reelection bids in 1934.

\section{The timing of state legalization after passage of the Beer Bill}

The Cullen-Harrison Act altered the federal Prohibition law to allow for $3.2 \%$ beer-but almost all states had their own Prohibition laws on the books and the strongest of the federal or state (or local) law was the one that was binding. In short, even after Cullen-Harrison went into effect, beer would not be legal in any state that did not remove its prohibitions and create its own system for controlling beer. In this section, we examine the factors that influenced the speed with which states legalized in the wake of the beer bill's passage. Twenty-one states legalized on April 7, while the remaining 27 states legalized after that date, but prior to May 2, 1937. In this exercise, we examine legislative behavior not at the federal level, but at the state level—specifically, we analyze whether state legislatures took action to legalize beer more quickly based upon the four factors—personal

${ }^{41}$ Congressional Record, 77 $7^{\text {th }}$ Congress, Record 503, March 16, 1933 p. 531.

${ }^{42}$ Congressional Record, $77^{\text {th }}$ Congress, Record 503, March 16, 1933 p. 534. 
ideological preferences, voter preferences, special interest effects, and national party identityexamined in the previous section.

To explore this issue, we create a new variable, MONTHBEER $i$, which takes on the value of the number of months beyond April 1933 that a state legalized beer. For a state that legalized in April 1933, the variable takes is set at zero, for May 1933, a one, and so on. ${ }^{43}$ The average value of the MONTHBEERi variable is 3.8. Because the dependent variable employs count data, we estimate the following Poisson regression:

$$
\begin{aligned}
\text { Monthbeer }_{i}= & \beta_{0}+\beta_{1} \text { Ideology }_{i}+\beta_{2} \text { Democrat }_{i}+\beta_{3} \text { pctFDRvote }_{i}+\beta_{4} \text { Voteshift }_{i} \\
& +\beta_{5} \text { Brewinginterest }_{i}+\beta_{6} \text { Agriculture }_{i}+Z_{i}^{\prime} \delta+\varepsilon_{i}
\end{aligned}
$$

As was the case in the analysis reported in Table 4, Ideology $y_{i}$ represents the average House DWNOMINATE score for state $i$ measured on both dimensions again. Democrat ${ }_{i}$ represents whether or not a state's governor was a member of the Democratic Party in 1933. The other variables are the same as in the prior analysis and we again report three separate specifications that vary based on the inclusion of our three different measures of brewing interests (breweries per capita in 1914, 1932, and beer barrels per capita in 1914). The results are reported in Table $5 .{ }^{44}$

[Insert Table 5 About Here]

\footnotetext{
${ }^{43}$ We use the $12^{\text {th }}$ day of the month as the cutoff so that, for example, if a state legalized on April 12 it received a zero, but if between April 13 and May 12, it received a one. We tried alternative cutoff dates such as the $15^{\text {th }}$ and the $20^{\text {th }}$ of the month, and the results are not qualitatively different throughout the study.

${ }^{44}$ We also consider these specifications excluding the DW-NOMINATE score, since this may not perfectly reflect state-level legislative preferences. Overall, the results are qualitatively the same, save for the coefficient on per capita barrels of beer produced, which shifts from being marginally significant to insignificant. Given the comparable results between the specifications, we do not report these in the interest of space. However, they are available upon request.
} 
Because MONTHBEER rises as states delay legalization, a negative coefficient on the independent variables indicates that a higher value of that variable led to a state legalizing sooner after April 1933. Here the only coefficients that are consistently significant are those related to preexisting brewing interests and, interestingly, the Southern dummy, with those results suggesting more rapid legalization. These findings suggest that the most influential driver of legalization at the state level was the size of the brewing interests. ${ }^{45}$

\section{Conclusion}

Many studies have examined the political economy of New Deal federal spending during the 1930s. While some disagreement exists regarding the degree to which the geographic distribution of New Deal spending was driven by political objectives, especially those of FDR, the consensus finding is that politics mattered. In this study, we examine the political behavior behind one of the earliest New Deal policies—-the so-called “beer bill,” which President Franklin Roosevelt signed into law just 17 days after he took office. Specifically, we look for evidence consistent with the four major drivers of voting behavior highlighted in the literature: 1) legislator ideological preferences, 2) voter preferences, 3) special interest effects, and 4) national party identity.

While the Cullen-Harrison Act, which amended the federal Prohibition law (the Volstead Act) to allow for $3.2 \%$ alcohol beer, quickly passed both the House and the Senate, the final votes were far from unanimous. Representatives from traditional beer producing states, such as

\footnotetext{
${ }^{45}$ We also considered negative binomial regressions for robustness. Overall, there are only marginal differences to report. Most importantly, each of the results for preexisting brewing interests maintain the same sign coefficients and are statistically significant. While these results have been excluded for the sake of space, they are available upon request.
} 
Wisconsin and Missouri, took to the House floor to push strongly for legalization, while politicians from many Southern states—which generally had little brewing tradition and whose farmers did not specialize in growing key beer inputs, such as barley—spoke against the bill, saying that the primary jobs it would create would be those for undertakers, policemen and bartenders. In fact, our results consistently show that one of the most important determinants of votes on beer legalization was the extent that the representative's state had strong brewing interests (proxied by past or current breweries or a brewing tradition). Thus, we find strong evidence consistent with the special interest hypothesis. We also generally find that Democratic politicians were more likely to vote in favor of beer legalization, consistent with the national party identity hypothesis. The evidence with respect to personal ideological preferences is weaker, but it does appear that representatives' ideology played at least a marginal role, as more conservative politicians were often less likely to vote in favor of beer, ceteris paribus. We find no evidence, however, consistent with the voter preferences/median voter hypothesis, at least once controlling for a given legislator's ideological position. If anything, representatives from states that Roosevelt won or swung more strongly his way between 1932 and 1936 were less likely to vote for beer, ceteris paribus. However, to the extent that the results are detecting constituent rather than legislator ideology, future research could more deeply evaluate this possibility.

The federal passage of the beer bill in March of 1933 merely gave states the ability to legalize 3.2 beer. States had to take further action to amend their own prohibition laws and set up a system to control and tax beer. By April 7, 1933, the first date at which beer could be legalized, 21 of the 48 states had acted to do so. The majority of the remaining states legalized sporadically prior to the end of 1933—and the final five states removed their beer Prohibitions between 1934 and 1937. Thus, we also test to see whether the speed of legalization at the state level (a function 
of the behavior of state congressional delegations) was driven by any of the four factors outlined above. We find strong support only for the special interest hypothesis—states with more brewing interests legalized more quickly than otherwise. Our findings broadly concur with Anderson and Tollison (1991), amongst others, who have shown that voting behavior during the birth of big (federal) government in the United States during the New Deal conformed with many of the predictions of public choice theory.

\section{References}

Anderson, G. M., \& Tollison, R. D. (1991). Congressional influence and patterns of New Deal spending, 1933-1939. Journal of Law and Economics, 34 (1), 161-175.

Baldwin, R. E., \& Christopher, S. M. (1985). Is Trade Policy for Sale? Congressional Voting on Recent Trade Bills. In NBER Working Paper 6376.

Baldwin, R. E. (1985). The political economy of U.S. import policy. Cambridge, MA: The MIT Press.

Bender, B., \& John, R. L. Jr. (1996). Legislator Voting and Shirking: A Critical Review of the Literature. Public Choice, 87(1-2), 67-100.

Burden, B. C., Gregory, A. C., \& Tim, G. (2000). Measuring the Ideologies of U.S. Senators: The Song Remains the Same. Legislative Studies Quarterly, 25(2), 237-258.

Cherrington, E. H. (1915). Prohibition Text Book: Facts and Figures Dealing with the Liquor Traffic. Westervillle, OH: The American Issue Publishing Company.

Choi, Y. (2015). Constituency, Ideology, and Economic Interest in U.S. Congressional Voting: The Case of the U.S. - Korea Free Trade Agreement. Political Research Quarterly, 68(2), 266-279.

Couch, J. F., \& Shughart, W. F. II. (1998). The Political Economy of the New Deal. Northampton: Edward Elgar.

Coughlin, C. C. (1985). Domestic Content Legislation: House Voting and the Economic Theory of Regulation. Economic Inquiry, 23 (3), 437-448. 
Cox, G. W., \& Mathew D. M. (1993). Legislative Leviathan: Party Government in the House. California Series on Social Choice and Political Economy, 23. Berkley: University of California.

Fiorina, M. P. (1974). Representatives, Roll Calls, and Constituencies. Lexington Books.

Fleck, R. K. (1999). Electoral Incentives, Public Policy, and the New Deal Realignment. Southern Economic Journal, 63, 377-404.

Fleck, R. K. (2001a). Inter-Party Competition, Intra-Party Competition, and Distributive Policy: A Model and Test Using New Deal Data. Public Choice, 108, 77-100.

Fleck, R. K. (2001b). Population, Land, Economic Conditions, and the Allocation of New Deal Spending. Explorations in Economic History, 38, 296-304.

Fleck, R. K. (2002). Democratic Opposition to the Fair Labor Standards Act of 1938. The Journal of Economic History, 62(1), 25-54.

Goff, B. L., \& Kevin B. G. (1993). On the (Mis)measurement of Legislator Ideology and Shirking. Public Choice, 76(1-2), 5-20.

Griffin, J. D. (2008). Measuring Legislator Ideology. Social Science Quarterly, 89 (2), 337-350.

Jackson, J. E., \& John W. K. (1992). Ideology, Interest Group Scores, and Legislative Votes. American Journal of Political Science, 36(3), 805-823.

Kahane, L. H. (1996). Congressional Voting Patterns on NAFTA. The American Journal of Economics and Sociology, 55(4), 395-409.

Kantor, S., Price, F., \& John, J. W. (2013). Did the New Deal Solidify the 1932 Democratic Realignment? Explorations in Economic History, 50, 620-633.

Kiewiet, D. R., \& Matthew D. M. (1991). The Logic of Delegation. Chicago: University of Chicago Press.

Kyvig, D. E. (1979). Repealing National Prohibition. Chicago: University of Chicago Press.

Levitt, S. D. (1996). How do Senators Vote? Disentangling the Role of Voter Preferences, Party Affiliation, and Senator Ideology. The American Economic Review, 86(3), 425-551.

Lott, J. R. Jr. (1987). Political Cheating. Public Choice, 52(2), 169-186.

Marks, S. V. (1993). Economic Interests and Voting on the Omnibus Trade Bill of 1987. Public Choice, 75(1), 21-42. 
Martis, K. C. (1982). The Historical Atlas of United States Congressional Districts, 1789-1983. Free Press.

McArthur, J., \& Stephen, M. (1988). Constituent Interest vs. Legislator Ideology: The Role of Political Opportunity Cost. Economic Inquiry, 26(3), 461-470.

Okrent, D. (2010). Last Call: The Rise and Fall of Prohibition (New York: Scribner).

Olson, M. (1965). The Logic of Collective Action: Public Goods and the Theory of Groups. Cambridge, MA: Harvard University Press.

Poelmans, E., Samuel, R., \& Jason, E. T. (2017). Three-Two Beer, One Recovery: The 'Beer Bill' and the Economic Turnaround of Spring 1933. Working Paper.

Poole, K. T., \& Howard, R. (1984). The Polarization of American Politics. The Journal of Politics, 46(4), 1061-1079.

Poole, K. T., \& Howard, R. (2007). Ideology \& Congress: A Political-Economic History of Roll Call Voting. Transaction Publishers: New Brunswick, NJ.

Reading, D. C. (1973). New Deal Activity and the States. Journal of Economic History, 36, 792810.

Rohde, D. (1991). Parties and Leaders in the Postreform House. Chicago, IL: University of Chicago Press.

Rohde, D. (1994). Parties and Committees in the House: Member Motivations, Issues, and Institutional Arrangements. Legislative Studies Quarterly, 19(3), 341-359.

Selzter, A. J. (1995). The Political Economy of the Fair Labor Standards Act of 1938. Journal of Political Economy, 103(6), 1302-1342.

Steagall, J. W., \& Ken, J. (1996). Unions, PAC contributions, and the NAFTA vote. Journal of Labor Research, 17(3), 515-521.

Tosini, S. C., \& Edward, T. (1987). The Textile Bill of 1985: The Determinants Of Congressional Voting Patterns. Public Choice, 54(1), 19-25.

Tullock, G. (1989). The Economics of Special Privilege and Rent Seeking. Boston: Kluwer Academic Publishers.

Wallis, J. J. (1984). The Birth of Old Federalism: Financing the New Deal. Journal of Economic History, 44, 139-59.

Wallis, J. J. (1998). The Political Economy of New Deal Spending Revisited, Again; With and Without Nevada. Explorations in Economic History, 35, 140-170. 
Weller, N. (2009). Trading Policy: Constituents and Party in U.S. Trade Policy. Public Choice, $141,87-101$.

Wright, G. (1974). The Political Economy of New Deal Spending. The Review of Economics and Statistics, 59, 30-38. 
Table 1

Date of legalization in each state, percentage of vote in favor of the Beer Bill and state-level data on beer interests

\begin{tabular}{|c|c|c|c|c|c|c|c|}
\hline State & $\begin{array}{c}\text { Date of } \\
\text { Legalization }\end{array}$ & $\begin{array}{l}\text { Propor- } \\
\text { tion } \\
\text { Voting } \\
\text { Yes on } \\
\text { Beer } \\
\text { Bill }\end{array}$ & $\begin{array}{c}\text { Brew- } \\
\text { eries } \\
1914 \\
\text { Per } \\
\text { Million } \\
\text { People }\end{array}$ & $\begin{array}{c}\text { Barrels Per } \\
\text { Capita } 1914\end{array}$ & $\begin{array}{c}\text { Brew- } \\
\text { eries } \\
1932 \\
\text { Per } \\
\text { Million } \\
\text { People }\end{array}$ & $\begin{array}{c}\text { Barley } \\
\text { Bushels } \\
\text { Produced } \\
1929\end{array}$ & $\begin{array}{l}\text { Pounds of } \\
\text { Hops } \\
\text { Produced } \\
1929\end{array}$ \\
\hline Alabama & Mar 22, 1937 & 0.55 & 0.94 & 0.02 & 0.38 & 1,472 & 0 \\
\hline Arizona & Jun 16,1933 & 0.50 & 19.57 & 0.10 & 0.00 & 235,072 & 0 \\
\hline Arkansas & Aug 24, 1933 & 0.22 & 0.64 & 0.01 & 0.00 & 1,859 & 0 \\
\hline California & Apr 7, 1933 & 0.86 & 35.33 & 0.59 & 2.11 & $29,038,344$ & $9,700,000$ \\
\hline Colorado & Apr 7, 1933 & 0.50 & 15.02 & 0.47 & 1.93 & $10,706,025$ & 0 \\
\hline Connecticut & Apr 20,1933 & 1.00 & 20.63 & 0.71 & 0.62 & 471 & 0 \\
\hline Delaware & Apr 7, 1933 & 0.33 & 24.71 & 0.68 & 0.00 & 4,067 & 0 \\
\hline Florida & May 8, 1933 & 1.00 & 2.66 & 0.03 & 0.68 & 0 & 0 \\
\hline Georgia & May 23, 1935 & 0.18 & 1.53 & 0.05 & 0.00 & 10,909 & 0 \\
\hline Idaho & Jun 21, 1933 & 0.50 & 21.50 & 0.06 & 0.00 & $4,247,839$ & 0 \\
\hline Illinois & Apr 7, 1933 & 0.93 & 17.56 & 1.24 & 2.62 & $9,381,100$ & 0 \\
\hline Indiana & Apr 7, 1933 & 0.79 & 15.18 & 0.65 & 3.40 & 688,045 & 0 \\
\hline Iowa & Apr 15, 1933 & 0.64 & 9.89 & 0.23 & 1.21 & $17,417,137$ & 0 \\
\hline Kansas & May 1,1937 & 0.00 & 0.59 & 0.00 & 0.00 & $9,466,268$ & 0 \\
\hline Kentucky & Apr 7, 1933 & 0.82 & 7.86 & 0.37 & 0.38 & 115,625 & 0 \\
\hline Louisiana & Apr 13, 1933 & 0.80 & 6.64 & 0.32 & 1.90 & 2,194 & 0 \\
\hline Maine & Jun 30,1933 & 0.40 & 0.00 & 0.00 & 0.00 & 73,335 & 0 \\
\hline Maryland & Apr 7, 1933 & 0.75 & 13.90 & 0.91 & 2.45 & 286,208 & 0 \\
\hline Massachusetts & Apr 7, 1933 & 0.94 & 10.10 & 0.75 & 0.71 & 1,504 & 0 \\
\hline Michigan & Apr 27, 1933 & 0.84 & 25.62 & 0.75 & 2.48 & $7,178,549$ & 0 \\
\hline Minnesota & Apr 7, 1933 & 0.89 & 33.24 & 0.84 & 3.90 & $47,639,628$ & 0 \\
\hline Mississippi & Feb 26, 1934 & 0.22 & 0.00 & 0.00 & 0.00 & 360 & 0 \\
\hline Missouri & Apr 7, 1933 & 0.93 & 14.27 & 1.26 & 1.38 & 126,359 & 0 \\
\hline Montana & Apr 7, 1933 & 1.00 & 58.50 & 0.77 & 3.72 & $3,798,109$ & 0 \\
\hline
\end{tabular}


Table 1 Continued

\begin{tabular}{|c|c|c|c|c|c|c|c|}
\hline State & $\begin{array}{c}\text { Date of } \\
\text { Legalization }\end{array}$ & $\begin{array}{c}\text { Propor- } \\
\text { Voting } \\
\text { Yes on } \\
\text { Beer } \\
\text { Bill }\end{array}$ & $\begin{array}{c}\text { Brew- } \\
\text { eries } \\
1914 \\
\text { Per } \\
\text { Million } \\
\text { People }\end{array}$ & Barrels Per & $\begin{array}{c}\text { Brew- } \\
\text { eries } \\
1932 \\
\text { Capita 1914 } \\
\text { Million } \\
\text { People }\end{array}$ & $\begin{array}{c}\text { Barley } \\
\text { Bushels } \\
\text { Produced } \\
1929\end{array}$ & $\begin{array}{c}\text { Pounds of } \\
\text { Hops } \\
\text { Produced } \\
1929\end{array}$ \\
\hline Nebraska & May 8, 1933 & 0.83 & 13.42 & 0.38 & 3.63 & $15,264,262$ & 0 \\
\hline Nevada & Apr 7, 1933 & 1.00 & 36.64 & 0.21 & 10.98 & 196,823 & 0 \\
\hline New Hampshire & May 2, 1933 & 0.50 & 9.29 & 0.66 & 0.00 & 4,345 & 0 \\
\hline New Jersey & Apr 7, 1933 & 1.00 & 15.37 & 1.38 & 1.73 & 23,784 & 0 \\
\hline New Mexico & Jun 9, 1933 & 0.33 & 6.11 & 0.03 & 0.00 & 145,976 & 0 \\
\hline New York & Apr 7, 1933 & 0.85 & 18.32 & 1.54 & 2.30 & $1,548,560$ & 332 \\
\hline North Carolina & Apr 28, 1933 & 0.62 & 0.00 & 0.00 & 0.00 & 328,746 & 0 \\
\hline North Dakota & Jul 1, 1933 & 0.25 & 3.47 & 0.00 & 2.94 & $38,154,988$ & 0 \\
\hline Ohio & Apr 7, 1933 & 0.81 & 24.96 & 1.08 & 3.01 & $1,978,779$ & 0 \\
\hline Oklahoma & Jul 15, 1933 & 0.27 & 0.00 & 0.00 & 0.00 & $1,138,515$ & 0 \\
\hline Oregon & Apr 7, 1933 & 1.00 & 19.32 & 0.32 & 3.15 & $2,373,155$ & $18,445,000$ \\
\hline Pennsylvania & April 7, 1933 & 0.74 & 30.92 & 1.04 & 1.97 & 570,633 & 0 \\
\hline Rhode Island & Apr 7, 1933 & 1.00 & 12.90 & 1.27 & 0.00 & 383 & 0 \\
\hline South Carolina & Apr 14, 1933 & 0.75 & 1.32 & 0.00 & 0.58 & 20,316 & 0 \\
\hline South Dakota & Aug 5, 1933 & 0.75 & 6.85 & 0.08 & 1.44 & $35,652,875$ & 0 \\
\hline Tennessee & May 1, 1933 & 0.64 & 1.83 & 0.10 & 0.00 & 210,488 & 0 \\
\hline Texas & Sep 15, 1933 & 0.41 & 4.36 & 0.19 & 0.69 & 3743677 & 0 \\
\hline Utah & Jan 1, 1934 & 1.00 & 13.39 & 0.40 & 0.00 & $1,453,021$ & 0 \\
\hline Vermont & Apr 7, 1933 & 0.33 & 0.00 & 0.00 & 0.00 & 83,149 & 0 \\
\hline Virginia & Sep 3, 1933 & 0.64 & 2.91 & 0.10 & 0.00 & 331,884 & 0 \\
\hline Washington & Apr 7, 1933 & 1.00 & 28.02 & 0.85 & 3.84 & $1,539,224$ & $5,075,000$ \\
\hline West Virginia & Apr 12, 1933 & 0.71 & 9.01 & 0.28 & 0.00 & 21,182 & 0 \\
\hline Wisconsin & Apr 7, 1933 & 0.92 & 66.84 & 2.26 & 10.89 & $18,646,647$ & 0 \\
\hline Wyoming & May 19, 1933 & 1.00 & 13.70 & 0.11 & 0.00 & $2,738,673$ & 0 \\
\hline
\end{tabular}


Table 2: Probit Results

Dependent Variable $=$ Senate Vote on March 16th and 20th

\begin{tabular}{|c|c|c|c|c|c|c|}
\hline \multirow[t]{2}{*}{ VARIABLES } & (1) & $(2)$ & (3) & (4) & (5) & (6) \\
\hline & March 16th & March 16th & March 16th & March 20th & March 20th & March 20th \\
\hline \multirow[t]{2}{*}{ Senator DW-NOMINATE 1st Dimension } & -0.267 & -0.354 & -0.206 & 0.109 & -0.00338 & 0.110 \\
\hline & $(0.294)$ & $(0.325)$ & $(0.322)$ & $(0.256)$ & $(0.255)$ & $(0.268)$ \\
\hline \multirow[t]{2}{*}{ Senator DW-NOMINATE 2nd Dimension } & -0.105 & -0.0716 & 0.0416 & -0.129 & -0.0818 & -0.0513 \\
\hline & $(0.165)$ & $(0.161)$ & $(0.160)$ & $(0.145)$ & $(0.138)$ & $(0.132)$ \\
\hline \multirow[t]{2}{*}{ Democrat (1=Yes) } & $0.397 * *$ & 0.255 & $0.372 *$ & $0.429 * *$ & $0.306^{*}$ & $0.414^{* *}$ \\
\hline & $(0.201)$ & $(0.210)$ & $(0.198)$ & $(0.175)$ & $(0.178)$ & $(0.177)$ \\
\hline \multirow[t]{2}{*}{ \% FDR vote in 1932} & 0.00128 & 0.0115 & 0.00379 & -0.00386 & 0.00164 & -0.000449 \\
\hline & $(0.00659)$ & $(0.00711)$ & $(0.00677)$ & $(0.00452)$ & $(0.00468)$ & $(0.00487)$ \\
\hline \multirow[t]{2}{*}{ Pounds of Hops and Barley (in million) } & $-8.04 \mathrm{e}-05$ & $-8.93 e-05$ & $1.91 \mathrm{e}-05$ & $7.90 \mathrm{e}-05$ & 7.93e-05 & 0.000114 \\
\hline & $(0.000153)$ & $(0.000137)$ & $(0.000141)$ & $(0.000119)$ & $(0.000108)$ & $(0.000115)$ \\
\hline \multirow[t]{2}{*}{ Per capita breweries in 1932} & $153,153 * * *$ & & & $100,199 * *$ & & \\
\hline & $(41,659)$ & & & $(43,679)$ & & \\
\hline \multirow[t]{2}{*}{ Per capita breweries in 1914} & & $23,303 * * *$ & & & $19,058 * * *$ & \\
\hline & & $(5,784)$ & & & $(4,714)$ & \\
\hline \multirow[t]{2}{*}{ Per capita beer barrels produced (in millions) } & & & $0.479 * * *$ & & & $0.357 * * *$ \\
\hline & & & $(0.142)$ & & & $(0.137)$ \\
\hline \multirow[t]{2}{*}{ \% change in Democratic vote for president } & $-0.00480 *$ & $-0.00533 *$ & -0.00371 & $-0.00557 * * *$ & $-0.00568 * * *$ & $-0.00481 * *$ \\
\hline & $(0.00252)$ & $(0.00272)$ & $(0.00269)$ & $(0.00192)$ & $(0.00177)$ & $(0.00189)$ \\
\hline \multirow[t]{2}{*}{ Senator Tenure } & $0.0130 * *$ & 0.0107 & $0.0158 * *$ & 0.000527 & -0.00124 & 0.00256 \\
\hline & $(0.00647)$ & $(0.00662)$ & $(0.00651)$ & $(0.00784)$ & $(0.00729)$ & $(0.00743)$ \\
\hline \multirow[t]{2}{*}{ \% change in employment 1929 to 1931} & 0.986 & $2.154 * * *$ & 0.713 & -0.634 & 0.0348 & -0.670 \\
\hline & $(0.691)$ & $(0.720)$ & $(0.747)$ & $(0.481)$ & $(0.529)$ & $(0.562)$ \\
\hline \multirow[t]{2}{*}{ Per capita value of manufacturing output in 1929} & 0.00523 & 0.00376 & 0.00201 & 0.00564 & 0.00373 & 0.00274 \\
\hline & $(0.00745)$ & $(0.00723)$ & $(0.00710)$ & $(0.00739)$ & $(0.00595)$ & (0.00739) \\
\hline \multirow[t]{2}{*}{ \% Catholic } & 0.00218 & -0.00211 & -0.00302 & -0.000152 & -0.000651 & -0.00318 \\
\hline & $(0.00564)$ & $(0.00617)$ & $(0.00653)$ & $(0.00478)$ & $(0.00430)$ & $(0.00511)$ \\
\hline \multirow[t]{2}{*}{ South (1=Yes) } & -0.129 & -0.261 & -0.215 & -0.0799 & -0.0727 & -0.191 \\
\hline & $(0.183)$ & $(0.190)$ & $(0.191)$ & $(0.156)$ & $(0.154)$ & $(0.153)$ \\
\hline Pseudo R-squared & 0.381 & 0.335 & 0.320 & 0.372 & 0.397 & 0.333 \\
\hline Observations & 73 & 73 & 73 & 79 & 79 & 79 \\
\hline
\end{tabular}

Standard errors clustered by state in parentheses. Coefficients are reported as marginal effects.

*** $\mathrm{p}<0.01, * * \mathrm{p}<0.05, * \mathrm{p}<0.1$ 
Table 3: House of Representatives Vote Results

Dependent Variable $=$ Percentage of State House Delegation Voting "Yes"

\begin{tabular}{|c|c|c|c|c|c|c|c|c|c|}
\hline & (1) & $(2)$ & (3) & (4) & (5) & (6) & (7) & (8) & (9) \\
\hline VARIABLES & OLS & Tobit & Logit & OLS & Tobit & Logit & OLS & Tobit & Logit \\
\hline \multirow[t]{2}{*}{ Average House DW-NOMINATE 1st Dimension } & -0.0712 & -0.283 & -0.181 & -0.103 & -0.421 & -0.282 & -0.0303 & -0.252 & -0.214 \\
\hline & $(0.328)$ & $(0.486)$ & $(0.241)$ & $(0.336)$ & $(0.546)$ & $(0.276)$ & $(0.350)$ & $(0.535)$ & $(0.259)$ \\
\hline \multirow[t]{2}{*}{ Average House DW-NOMINATE 2nd Dimension } & $-0.288 * *$ & $-0.584 * *$ & $-0.345^{* * *}$ & $-0.223 *$ & $-0.391 *$ & $-0.223^{*}$ & $-0.309 * *$ & $-0.602 * *$ & $-0.368 * * *$ \\
\hline & $(0.138)$ & $(0.237)$ & $(0.130)$ & $(0.127)$ & $(0.227)$ & $(0.130)$ & $(0.130)$ & $(0.233)$ & $(0.126)$ \\
\hline \multirow[t]{2}{*}{ \% House Delegation Democrat } & $0.295^{*}$ & $0.360 *$ & $0.206^{* *}$ & 0.259 & 0.240 & 0.116 & $0.315^{*}$ & $0.388^{*}$ & $0.218^{* *}$ \\
\hline & $(0.170)$ & $(0.189)$ & $(0.0849)$ & $(0.172)$ & $(0.235)$ & $(0.122)$ & $(0.179)$ & $(0.219)$ & $(0.110)$ \\
\hline \multirow[t]{2}{*}{ \% FDR vote in 1932} & $-0.00622 *$ & -0.00603 & -0.00328 & -0.00468 & -0.00391 & -0.00211 & -0.00440 & -0.00363 & -0.00181 \\
\hline & $(0.00365)$ & $(0.00544)$ & $(0.00278)$ & $(0.00355)$ & $(0.00523)$ & $(0.00254)$ & $(0.00368)$ & $(0.00529)$ & $(0.00265)$ \\
\hline \multirow[t]{2}{*}{ Pounds of Hops and Barley (in million) } & $7.34 \mathrm{e}-06$ & $-2.78 \mathrm{e}-05$ & $-2.98 \mathrm{e}-05$ & $-1.32 \mathrm{e}-05$ & $-8.94 \mathrm{e}-05$ & $-4.25 e-05$ & $1.93 e-05$ & $9.51 \mathrm{e}-06$ & $2.08 \mathrm{e}-05$ \\
\hline & $(5.57 e-05)$ & $(7.51 \mathrm{e}-05)$ & $(3.85 e-05)$ & $(5.58 \mathrm{e}-05)$ & $(8.98 \mathrm{e}-05)$ & $(5.10 \mathrm{e}-05)$ & $(5.92 \mathrm{e}-05)$ & $(8.42 \mathrm{e}-05)$ & $(4.98 \mathrm{e}-05)$ \\
\hline \multirow[t]{2}{*}{ Per capita breweries in 1932} & $26,880 * *$ & $57,487^{*}$ & 49,996* & & & & & & \\
\hline & $(10,051)$ & $(30,698)$ & $(28,298)$ & & & & & & \\
\hline \multirow[t]{2}{*}{ Per capita breweries in 1914} & & & & $4,767 * *$ & $13,461 * *$ & $8,343^{* * *}$ & & & \\
\hline & & & & $(1,989)$ & $(5,091)$ & $(3,007)$ & & & \\
\hline \multirow[t]{2}{*}{ Per capita beer barrels produced (in millions) } & & & & & & & 0.0812 & 0.183 & 0.0966 \\
\hline & & & & & & & $(0.0669)$ & $(0.125)$ & $(0.0780)$ \\
\hline \multirow[t]{2}{*}{$\%$ change in Democratic vote for president } & -0.00207 & -0.00271 & $-0.00168 *$ & -0.00195 & -0.00292 & $-0.00170^{*}$ & -0.00163 & -0.00217 & -0.00153 \\
\hline & $(0.00211)$ & $(0.00238)$ & $(0.00100)$ & $(0.00204)$ & $(0.00221)$ & $(0.000922)$ & $(0.00219)$ & $(0.00258)$ & $(0.00112)$ \\
\hline \multirow[t]{2}{*}{ \% change in employment 1929 to 1931} & 0.125 & -0.208 & 0.0819 & 0.376 & 0.350 & 0.404 & 0.0934 & -0.252 & 0.124 \\
\hline & $(0.610)$ & $(0.767)$ & $(0.381)$ & $(0.627)$ & $(0.831)$ & $(0.409)$ & $(0.634)$ & $(0.850)$ & $(0.443)$ \\
\hline \multirow[t]{2}{*}{ Per capita value of manufacturing output in 1929} & -0.00298 & $-0.0103 * * *$ & $-0.00570 * * *$ & -0.00291 & $-0.0110 * * *$ & $-0.00579 * *$ & $-0.00398 *$ & $-0.0126 * * *$ & $-0.00639 *$ \\
\hline & $(0.00203)$ & $(0.00342)$ & $(0.00199)$ & $(0.00218)$ & $(0.00380)$ & $(0.00231)$ & $(0.00223)$ & $(0.00428)$ & $(0.00330)$ \\
\hline \multirow[t]{2}{*}{ \% Catholic } & -0.00101 & -0.00325 & -0.00122 & -0.000670 & -0.00178 & 0.000114 & -0.00201 & -0.00465 & -0.00159 \\
\hline & $(0.00396)$ & $(0.00630)$ & $(0.00338)$ & $(0.00370)$ & $(0.00585)$ & $(0.00294)$ & $(0.00426)$ & $(0.00675)$ & $(0.00331)$ \\
\hline \multirow[t]{2}{*}{ South (1=Yes) } & 0.00396 & -0.0236 & 0.00987 & -0.0416 & -0.0812 & -0.0215 & -0.0504 & -0.106 & -0.0460 \\
\hline & $(0.116)$ & $(0.202)$ & $(0.103)$ & $(0.0962)$ & $(0.168)$ & $(0.0847)$ & $(0.101)$ & $(0.172)$ & $(0.0871)$ \\
\hline \multirow[t]{2}{*}{ Constant } & $1.114 * * *$ & $1.201^{* * *}$ & & $1.081^{* * *}$ & $1.201^{* * *}$ & & $1.005^{* * *}$ & $1.061^{* * *}$ & \\
\hline & $(0.277)$ & $(0.359)$ & & $(0.282)$ & $(0.373)$ & & $(0.291)$ & $(0.376)$ & \\
\hline R-squared & 0.541 & & & 0.536 & & & 0.511 & & \\
\hline Log-Likelihood & & -13.35 & -14.21 & & -12.33 & -14.13 & & -14.65 & -14.56 \\
\hline Observations & 47 & 47 & 47 & 47 & 47 & 47 & 47 & 47 & 47 \\
\hline
\end{tabular}

Standard errors clustered by state in parentheses. Coefficients reported for both the Tobit and Fractional Logit results are marginal effects.

$* * * \mathrm{p}<0.01, * * \mathrm{p}<0.05, * \mathrm{p}<0.1$ 
Table 4

Analysis of Congressional Testimony on the Beer Bill

Congressional Members Appear in Order of State's Rank in 1914 Beer Production

\begin{tabular}{|c|c|c|c|}
\hline Representative & Testimony & Senator & Testimony \\
\hline Cullen (New York) & Favor & Fess (Ohio) & Oppose \\
\hline Mead (New York) & Favor & Patterson (Missouri) & Oppose \\
\hline O’Connor (New York) & Favor & Kean (New Jersey) & Favor \\
\hline Celler (New York) & Favor & Walsh (Massachusetts) & Favor \\
\hline Lanzetta (New York) & Favor & Johnson (California) & Favor \\
\hline Boylan (New York) & Favor & Tydings (Maryland) & Favor \\
\hline Beck (Pennsylvania) & Favor & Dill (Washington) & Favor \\
\hline Rich (Pennsylvania) & Oppose & Barkley (Kentucky) & Favor \\
\hline Watson (Pennsylvania) & Favor & Sheppard (Texas) & Oppose \\
\hline Focht (Pennsylvania) & Oppose & Connally (Texas) & Oppose \\
\hline O’Malley (Wisconsin) & Favor & Norris (Nebraska) & Favor \\
\hline Frear (Wisconsin) & Favor & Hatfield (West Virginia) & Oppose \\
\hline Cannon (Wisconsin) & Favor & Hastings (Delaware) & Oppose \\
\hline Harlan (Ohio) & Favor & Borah (Idaho) & Oppose \\
\hline Young (Ohio) & Favor & Smith (South Carolina) & Oppose \\
\hline Sweeney (Ohio) & Favor & Capper (Kansas) & Oppose \\
\hline Britten (Illinois) & Favor & Harrison (Mississippi) & Favor \\
\hline Sabath (Illinois) & Favor & Bailey (North Carolina) & Oppose \\
\hline Lee (Missouri) & Favor & & \\
\hline Cochran (Missouri) & Favor & & \\
\hline Claiborne (Missouri) & Favor & & \\
\hline Kenney (New Jersey) & Favor & & \\
\hline Healey (Massachusetts) & Favor & & \\
\hline Treadway (Massachusetts) & Favor & & \\
\hline McCormack (Massachusetts) & Favor & & \\
\hline Sadowski (Michigan) & Favor & & \\
\hline Eltese (California) & Oppose & & \\
\hline Palmisano (Maryland) & Favor & & \\
\hline Blanton (Texas) & Oppose & & \\
\hline Eagle (Texas) & Favor & & \\
\hline McFarlane (Texas) & Oppose & & \\
\hline Strong (Texas) & Oppose & & \\
\hline Morehead (Nebraska) & Oppose & & \\
\hline Guyer (Kansas) & Oppose & & \\
\hline Mrs. McCarthy (Kansas) & Oppose & & \\
\hline Utterback (Maine) & Favor & & \\
\hline Rogers (Oklahoma) & Oppose & & \\
\hline
\end{tabular}

Source: Congressional Record, $77^{\text {th }}$ Congress, Record 310, March 14, 1933 and Record 503, March 16, 1933. 
Table 5: Poisson Regressions Results for State-Level Legalization Vote

Dependent Variable $=$ Number of Months for State Legalization

\begin{tabular}{|c|c|c|c|}
\hline & $(1)$ & $(2)$ & (3) \\
\hline \multirow[t]{2}{*}{ Average House DW-NOMINATE 1st Dimension } & -3.023 & -13.28 & -2.442 \\
\hline & $(7.614)$ & $(9.094)$ & $(8.948)$ \\
\hline \multirow[t]{2}{*}{ Average House DW-NOMINATE 2nd Dimension } & $6.574 *$ & -3.866 & 5.066 \\
\hline & $(3.433)$ & $(2.680)$ & $(3.084)$ \\
\hline \multirow[t]{2}{*}{ Democratic Governor (1=Yes) } & 0.407 & 0.189 & 0.0859 \\
\hline & (1.949) & $(1.574)$ & $(1.715)$ \\
\hline \multirow[t]{2}{*}{ \% FDR vote in 1932} & $0.247 *$ & $0.453 * *$ & 0.183 \\
\hline & $(0.133)$ & $(0.190)$ & $(0.141)$ \\
\hline \multirow[t]{2}{*}{ Pounds of Hops and Barley (in million) } & 0.00228 & $-0.00691^{* *}$ & -0.00259 \\
\hline & $(0.00158)$ & $(0.00291)$ & $(0.00166)$ \\
\hline \multirow[t]{2}{*}{ Per capita breweries in 1932} & $-4.622 \mathrm{e}+06 * * *$ & & \\
\hline & $(1.414 \mathrm{e}+06)$ & & \\
\hline \multirow[t]{2}{*}{ Per capita breweries in 1914} & & $-1.122 \mathrm{e}+06 * * *$ & \\
\hline & & $(406,569)$ & \\
\hline \multirow[t]{2}{*}{ Per capita beer barrels produced (in millions) } & & & $-22.57 *$ \\
\hline & & & $(12.88)$ \\
\hline \multirow[t]{2}{*}{ \% change in Democratic vote for president } & 0.0859 & $0.113 * *$ & 0.0756 \\
\hline & $(0.0554)$ & $(0.0450)$ & $(0.0500)$ \\
\hline \multirow[t]{2}{*}{ \% change in employment 1929 to 1931} & 12.02 & -4.835 & 0.264 \\
\hline & $(12.40)$ & $(9.039)$ & $(8.814)$ \\
\hline \multirow[t]{2}{*}{ Per capita value of manufacturing output in 1929} & 0.0116 & 0.120 & 0.429 \\
\hline & $(0.167)$ & $(0.100)$ & $(0.320)$ \\
\hline \multirow[t]{2}{*}{ \% Catholic } & -0.155 & $-0.375^{* * *}$ & -0.192 \\
\hline & $(0.107)$ & $(0.118)$ & $(0.126)$ \\
\hline \multirow[t]{2}{*}{ South (1=Yes) } & $-10.62 *$ & $-24.87 * * *$ & $-10.76 *$ \\
\hline & $(5.468)$ & $(9.477)$ & $(6.338)$ \\
\hline Log-Likelihood & -153.09 & -159.64 & -162.90 \\
\hline Observations & 48 & 48 & 48 \\
\hline
\end{tabular}

Standard errors clustered by state in parentheses. Coefficients are reported as marginal effects. *** $\mathrm{p}<0.01, * * \mathrm{p}<0.05,{ }^{*} \mathrm{p}<0.1$ 